\title{
Alleviation of Allelopathic Effect of Launae sonchoids Weed on Wheat Growth by Salicylic Acid
}

\section{H. E. Deef}

Botany Department, Faculty of Science, Zagazig University, Sharkia, Egypt.

\begin{abstract}
7 XPERIMENT for the study of alleviation of allelopathic effect of Launae sonchoids on wheat growth by pretreatment grains with salicylic acid (SA). Launae sonchoids was collected from the desert plains at Taif area, Saudia Arabia and sampled in March 2010. The germination and growth were conducted in the greenhouse during April 2010. Diluted extracts of Launae sonchoids shoot system was applied to pre-soaked in SA or non soaked wheat grains. The aqueous extract of Launae sonchoids at $25 \%$ caused an increase in the root and shoots growth and biomass production of the wheat seedlings at pre-soaked in SA or $\mathrm{H}_{2} \mathrm{O}$ comparison with control. The concentrated extracts (75 and 100\%) were phytotoxic to wheat germination. The percentage declined by pre-soaked wheat grains in $0.05 \mathrm{mM}$ salicylic acid. Betaine levels in seedlings pretreated with salicylic acid significant increase versus untreated seedlings, possibly because such a precursor promotes betaine biosynthesis. This could be responsible for the enhanced growth criteria and preventing the decrease in chlorophyll content in the pretreated seedlings. A relationship between nitrogenous fractions, antioxidant glutathione and Launae sonchoids extract tolerance observed in wheat seedlings with or without salicylic acid. Overall, the adverse effects of allelopathic stress could be alleviated by pre-treated with SA.
\end{abstract}

Keywords: Allelopathic, Launae sonchoids aqueous extract, Wheat growth, Salicylic acid, Betaine and non-protein thiols.

Allelopathy is the addition of plant-produced phytotoxins to the plant environment and competitive strategy of plants (Oussama, 2003). Accessions with an allelopathic effect have been found in many crops (Rice, 1984). Out of more than 3000 accessions of oat, several were found with a fluorescent microscope to exude a large amount of an allelochemical, scopoletin (Fay \& Duke, 1977). Biodegradable natural plant products rarely contain halogenated atoms and possess structural diversity and complexity; these can act directly as herbicides or may provide lead structures for herbicidal discovery (Bhadoria, 2011). Selection of allelopathic plants is a good and commonly used approach for identification of plants with biologically active natural products (Duke et al., 2000).

Corresponding author email: ragabtima@yahoo.com 
Allelochemicals are released from plant tissue in a variety of ways including emission, exudation, or leaching from above ground parts by rain, dew, fog, etc. (Ben Hammouda et al., 2001). Khanh et al. (2007) found that inhibitory substances involved in allelopathy are mainly terpenoids, and phenolic substances. Wide arrays of biologically active constituents are produced by plants in the genus Launae (Regina \& Belz, 2007). Bertholdesson, (2005) showed that volatile oil of Launae sonchoids have several biological activities, notably antibacterial, antifungal and antioxidative properties. Monoterpene vapors may cause anatomical and physiological changes in plant seedlings and exposure to volatile terpenes can lead to accumulation of lipid globules, reduction in organelles and disruption of membranes (Monari et al., 2005). Meanwhile the alkaloids gramine and hordenine caused damages to the cell walls, disorganization of organelles, increase cell vacuoles, and the appearance of lipid and globules of root tip cells (Rasmussen et al., 2004).

Salicylic acid is (SA) an endogenous growth regulator of phenolic nature (Hayat et al., 2010). Its role in the defense mechanisms against biotic and a biotic stress has been well documented (Szalai et al., 2000, Bosch et al., 2007 and Hussein et al., 2007). SA plays an important role in determining the sensitivity of plants to various a biotic stresses (Dat et al., 1998 and Rao \&Davis, 1999), notably at the seedling stage (Borsani et al., 2001 and Szepesi et al., 2005). The role of SA in defense mechanism to alleviate stress in plants was studied (Afzal et al., 2006; Hussein et al., 2007 and Javid et al., 2011). The ameliorative effects of SA have been well documented including salt tolerance in many crops such as bean (Azooz, 2009), tomato (Tari et al., 2002) and maize (Gunes et al., 2007). Moharekar et al. (2006) shows that the salicylic acid (SA), application increased chlorophyll content in both wheat and moong seedlings. Also Noreen \& Ashraf (2008) show that ameliorative effect of SA on plant growth under abiotic stress due to its role in nutrient uptake, water relations and stomatal regulation. Meanwhile, Taşgın et al. (2005) concluded that exogenous SA can be involved in cold tolerance by regulating apoplastic proteins and antioxidant enzyme activities. It was found that inhibition of catalase, a $\mathrm{H}_{2} \mathrm{O}_{2}$ scavenging enzyme by SA plays an essential role in the generation of reactive oxygen species (Horváth et al., 2002 and 2007). By increasing $\mathrm{H}_{2} \mathrm{O}_{2}$ concentration of the tissues, moderate doses of SA may activate the antioxidative mechanisms.

The present study was conducted to asses if the pretreatment wheat grains with low concentrations of SA could ameliorate the adverse allelopathic effects of Launae sonchoids on wheat growth. For this purposes growth characteristics, chlorophyll content, betaine, glutathione and nitrogenous fractions were measured.

\section{Preparation of extract}

\section{Materials and Methods}

Launae sonchoids was collected from the desert plains at Taif area and sampled in March 2010. Whole plants were pulled out of the field at the stage of flowering development. The plants were gently washed with distilled water,

Egypt. J. Agron. 34, No. 1 (2012) 
dried between two paper towels. The plant materials were chopped into $1 \mathrm{~cm}$ long pieces and dried at $50^{\circ} \mathrm{C}$ for $24 \mathrm{hr}$. The components were soaked in distilled water for $24 \mathrm{hr}$ at the rate of $5 \mathrm{~g}$ dry weight per $100 \mathrm{ml}$ distilled water. Extract was filtered through four layers of cheese cloth, Whitman filter paper under vacuum and stored at $<5^{\circ} \mathrm{C}$. Dilutions were made of the original extracts as, $100,75,50$, and $25 \%$ of the origin extracts.

\section{Culture and treatments}

The soil used in pots was sandy soil (85\% sand, $10 \%$ Silt and 5\% clay). Caryopses of wheat (Triticum aestivum L. CV, Gomeza 7) washed with running tap water and soaked for $30 \mathrm{sec}$ in $70 \%$ ethanol, disinfected with $20 \%(\mathrm{v} / \mathrm{v})$ sodium hypochlorite for $20 \mathrm{~min}$ and rinsed three times with sterile distilled water. Sterilized caryopses were divided two groups one soaked in water and other soaked in $0.05 \mathrm{mM}$ salicylic acid for $6 \mathrm{hr}$. Twenty caryopses were swon in each pot at relative humidity of $50 \pm 4 \%$, day/night temperature $30 / 20 \pm 2{ }^{\circ} \mathrm{C}$, and light intensity of $350.67 \pm 4.16$ Lux. in the greenhouse at Botany Department, Zagazig University, during April 2010. The experimental design was a complete randomized design with four replications.

The treatments were

$\mathrm{C}=$ Soaked in $\mathrm{H}_{2} \mathrm{O}$, irrigated with distilled $\mathrm{H}_{2} \mathrm{O}$

$\mathrm{LA}_{1}=$ Soaked in $\mathrm{H}_{2} \mathrm{O}$, irrigated with Launae extract, $25 \%$

$\mathrm{LA}_{2}=$ Soaked in $\mathrm{H}_{2} \mathrm{O}$,irrigated with Launae extract, $50 \%$

$\mathrm{LA}_{3}=$ Soaked in $\mathrm{H}_{2} \mathrm{O}$, irrigated with Launae extract, $75 \%$

$\mathrm{LA}_{4}=$ Soaked in $\mathrm{H}_{2} \mathrm{O}$, irrigated with Launae conc., extract $100 \%$

$\mathrm{SC}=$ Soaked in $0.05 \mathrm{mM}$ salicylic acid (SA), irrigated with distilled $\mathrm{H}_{2} \mathrm{O}$.

$\mathrm{SLA}_{1}=$ Soaked in $0.05 \mathrm{mM}$ salicylic acid, irrigated with Launae extract, $25 \%$

$\mathrm{SLA}_{2}=$ Soaked in $0.05 \mathrm{mM}$ salicylic acid, irrigated with Launae extract, $50 \%$

$\mathrm{SLA}_{3}=$ Soaked in $0.05 \mathrm{mM}$ salicylic acid, irrigated with Launae extract, $75 \%$

$\mathrm{SLA}_{4}=$ Soaked in $0.05 \mathrm{mM}$ salicylic acid, irrigated with Launae conc., extract $100 \%$

\section{Growth measurement}

Plant growth was estimated after 8 days (from germination) by measuring accumulation of root and shoot weight (after drying the plants material at $70^{\circ} \mathrm{C}$ for 48-72hr. Water content (WC) and degree of succulence (D. Su.) were measured according to Weatherly \& Barrs (1962) and expressed as a percentage according to the following equations:

$$
\begin{gathered}
\mathrm{WC}(\%)=(\mathrm{FW}-\mathrm{DW}) / \mathrm{FW} \times 100, \\
\text { D. Su. }=\mathrm{FW} / \mathrm{DW} .
\end{gathered}
$$


Analyses

Chlorophyll content

Concentration of chlorophyll a \& b in green tissues (leaf plus stem) of wheat seedlings at 2, 4, 6 and 8 days were estimated by the equations of Witham et al. (1971).

Betaine assay

$0.5 \mathrm{~g} \mathrm{FW}$ of wheat seedlings at 2, 4, 6 and 8 days were homogenized with $5 \mathrm{ml}$ of methanol and extracts were phase-separated with chloroform and water as described previously (Rhodes et al., 1987). After evaporating the aqueous phase to dryness in an air stream of distilled water and $0.3 \mathrm{ml}$ of slurry of Dowex 50 ion exchange resin in the $\mathrm{H}^{+}$form (Lerma et al., 1991) were added. Total betaine was determined according to the periodide method (Wall et al., 1960).

\section{Glutathione determination}

None-protein thiols were extracted by homogenizing $0.3 \mathrm{gm} \mathrm{FW}$ of wheat seedlings at 2, 4, 6 and 8 days in $1.5 \mathrm{ml}$ of $0.1 \mathrm{~N} \mathrm{HCl}$. After centrifugation at $15000 \mathrm{rpm}$ for $30 \mathrm{~min}$ at $4^{\circ} \mathrm{C}$, the supernatants were used for analysis. Total glutathione was determined in the homogenates by spectrophotometry at 412 nm (Schupp \& Rennenberg, 1988).

\section{Nitrogenous fractions}

Total nitrogen, soluble nitrogen; insoluble nitrogen and crude protein were measured in wheat seedlings after, 2, 4, 6 and 8 days from germination according to the conventional micro-Kjeldahl method (Pirie, 1955) and AOAC (1980).

\section{Statistical analysis}

Results indicated as mean values \pm SEM. Differences between control and treated samples were statistically analyzed by COSTAT and MSTATc computer programme and comparative analyses of the means were performed by LSD, least significantly different according to Fisher's test.

\section{Results and Discussion}

Effect of Launae sonchoids extracts in the presence or absence of SA on wheat caryopses germination

Launae sonchoids shoot extracts significantly affected germination of wheat caryopses in the presence or absence of SA (Table 1). Results obtained revealed that L. sonchoids allelopathy takes the form of heterotoxicity, depressive to wheat. The germination percentage of wheat caryopses after 2 days decreased more than 60 and $42 \%$ by Launae treatment at concentration of $\mathrm{LA}_{4}$ and $\mathrm{LA}_{3}$, respectively. The reduction decreased to 35 and $20 \%$ after 8 days, in the caryopses pre-soaked in $\mathrm{H}_{2} \mathrm{O}$. While at pre-soaked in SA the germination in day 8 decreased by 15 and $6 \%$ at $\mathrm{SLA}_{4}$ and $\mathrm{SLA}_{3}$, respectively. Treatment with $\mathrm{LA}_{1}$ extract had non-significant effect on the germination of wheat seeds, compared

Egypt. J. Agron. 34, No. 1 (2012) 
with control in the treated or untreated with SA. In general the negative effects of $L$. sonchoids extract on the germination of wheat caryopses increase with increasing the concentrations of extracts and this inhibition may be alleviated with pre-soaked the caryopses in SA.

TABLE 1. Effect of diluted extracts of Launae sonchoids on germination (\%) of wheat caryopses in the presence or absence of SA. Values are the means \pm SEM of three replicated measurements.

\begin{tabular}{|l|c|c|c|c|}
\hline \multirow{2}{*}{ Treatments } & \multicolumn{4}{|c|}{ Germination \% } \\
\cline { 2 - 5 } & \multicolumn{4}{|c|}{ Time (days) } \\
\cline { 2 - 5 } & $\mathbf{2}$ & $\mathbf{4}$ & $\mathbf{6}$ & $\mathbf{8}$ \\
\hline C & $64 \pm 5$ & $95 \pm 6$ & $100 \pm 6$ & $100 \pm 6$ \\
LA1 & $60 \pm 5$ & $88 \pm 5$ & $90 \pm 6$ & $92 \pm 6$ \\
LA3 & $44 \pm 4^{* *}$ & $65 \pm 5^{* *}$ & $80 \pm 5^{*}$ & $88 \pm 6^{* *}$ \\
LA4 & $34 \pm 3^{* * *}$ & $51 \pm 4^{* * *}$ & $74 \pm 5^{* *}$ & $80 \pm 6^{* *}$ \\
LSD, LA (5\%) & $22 \pm 2^{* * *}$ & $34 \pm 3^{* * *}$ & $46 \pm 4^{* * *}$ & $65 \pm 6^{* * *}$ \\
SC & 1.2 & 0.65 & 0.55 & 0.43 \\
SLA1 & $72 \pm 5$ & $100 \pm 6$ & $100 \pm 6$ & $100 \pm 6$ \\
SLA2 & $65 \pm 5$ & $90 \pm 6$ & $95 \pm 6$ & $100 \pm 6$ \\
SLA3 & $50 \pm 4$ & $84 \pm 5^{*}$ & $90 \pm 6$ & $98 \pm 6$ \\
SLA4 & $43 \pm 3^{* *}$ & $79 \pm 5^{*}$ & $85 \pm 5$ & $94 \pm 6$ \\
LSD, SLA (5\%) & $36 \pm 3^{* *}$ & $65 \pm 5^{* *}$ & $78 \pm 5^{* *}$ & $85 \pm 6^{*}$ \\
& 1.06 & 0.95 & 0.64 & 0.52 \\
\hline
\end{tabular}

Means within a column followed by different number of stars are significantly different according to Fisher's, ${ }^{*}=$ Significant at $\mathrm{P}<0.5{ }^{* *}=$ Significant at $\mathrm{P}<0.1$

${ }^{* * *}=$ Significant at $\mathrm{P}<0.05$

There are hundreds of secondary metabolites in the plants kingdom, and many are known to be phytotoxic (Einhellig, 2002). Allelopathic effects of these compounds are often observed to occur early in the life cycle, causing inhibition of germination and/or seedling growth (Halsey, 2004). The compounds exhibit a wide range of action mechanisms, from affects on DNA (alkaloids), photosynthetic and mitochondrial function (quinones), phytohormone activity, ion uptake, and water balance (phenolics). Interpretations of action mechanisms are complicated by the fact that individual compounds can have multiple phytotoxic effects (Einhellig, 2002).

Previous studies demonstrated that salicylic acid plays an important role in determining the sensitivity of plants to various a biotic stresses (Dat et al., 1998 and Rao \& Davis, 1999), notably at the seedling stage (Borsani et al., 2001). Lipid peroxidation and membrane permeability, which were increased by stress, were lower in SA treated plants (Horvath et al., 2007). SA treatment was accompanied by a transient increase in the $\mathrm{H}_{2} \mathrm{O}_{2}$ level. As caryopses treatment with $\mathrm{H}_{2} \mathrm{O}_{2}$ itself had an alleviating effect on the oxidative damage caused by stress in wheat plants (Wahid et al., 2007), it seems possible that SA may exert its protective effect partially through the transiently increased level of $\mathrm{H}_{2} \mathrm{O}_{2}$. 
Effect of Launae sonchoids extracts in the presence or absence of SA on wheat growth

To determine the allopathic effect of $L$. sonchoids on the growth of wheat seedlings the length and water content (WC) as well as dry weight of roots and shoots was measured either pre-soaked in $\mathrm{H}_{2} \mathrm{O}$ or SA (Table 2). The maximum shoot and root lengths were noticed at day $8 \mathrm{SC}$ samples. The reduction in the root and shoot lengths reached to 60 and $75 \%$ by treatment with Launae sonchoids $\mathrm{LA}_{3}$ and $\mathrm{LA}_{4}$, respectively. The root and shoot length of wheat seedlings were gradually decreased with the increase extract concentration from $\mathrm{LA}_{2}$ to $\mathrm{LA}_{4}$ at pre-soaked in $\mathrm{H}_{2} \mathrm{O}$. The length of the seedlings was significantly lower than that of the control, reaching a length more than three folds less at the $8^{\text {th }}$ day of treatment (Table 2) at pre-soaked in $\mathrm{H}_{2} \mathrm{O}$. Kil \& Yun (1992) shows that germination percentage and dry weight of wheat plants was slightly increased at lower concentrations of $L$. sonchoids extracts, whereas it was proportionally inhibited at higher concentrations.

TABLE 2. Effect of diluted extracts of Launae sonchoids on root and shoot lengths of 8 days old wheat plants, pre-soaked or none soaked in salicylic acid. Values are the means \pm SEM of three replicated measurements.

\begin{tabular}{|l|c|c|}
\hline \multicolumn{1}{|c|}{ Treatments } & Root length $(\mathbf{c m})$ & Shoot length $(\mathbf{c m})$ \\
\hline C & $4.9 \pm 0.4$ & $14.5 \pm 0.9$ \\
LA1 & $5.1 \pm 0.5$ & $15.2 \pm 1$ \\
LA2 & $3.5 \pm 0.3^{*}$ & $12.5 \pm 0.4^{*}$ \\
LA3 & $2.3 \pm 0.2^{* *}$ & $8.5 \pm 0.6^{* * * *}$ \\
LA4 & $1.6 \pm 0.2^{* * * *}$ & $6.7 \pm 0.4^{* * * *}$ \\
LSD, LA (5\%) & 0.26 & 0.92 \\
SC & $5.8 \pm 0.5$ & $16.8 \pm 1.1$ \\
SLA1 & $5.0 \pm 0.5$ & $14.2 \pm 1$ \\
SLA2 & $4.5 \pm 0.4$ & $13.5 \pm 0.7$ \\
SLA3 & $4.0 \pm 0.3^{*}$ & $12.6 \pm 0.7^{*}$ \\
SLA4 & $3.4 \pm 0.3^{*}$ & $10.7 \pm 0.6^{*}$ \\
LSD, SLA (5\%) & 0.36 & 1.2 \\
\hline
\end{tabular}

Means within a column followed by different number of stars are significantly different according to Fisher's, ${ }^{*}=$ Significant at $\mathrm{P}<0.5^{* *}=$ Significant at $\mathrm{P}<0.1{ }^{* * *}=$ Significant at $\mathrm{P}<0.05$.

Pre-soaked in SA alleviation the negative effect of the L. sonchoids allelopathy on shoot and root lengths.The protective effect of salicylic acid was shown by the greater length of SLA versus LA seedlings (Table 2). On the $8^{\text {th }}$ day, mean $\mathrm{SLA}_{4}$ lengths were more than twice as much as $\mathrm{LA}_{4}$ and were accompanied by the appearance of secondary roots in the seedlings. Treatment of wheat plants with $0.05 \mathrm{mM}$ SA increased the level of cell division within the apical meristem of seedling roots which increased the in plant growth (Javid et al., 2011).

Egypt. J. Agron. 34, No. 1 (2012) 
Water content and degree of succulence were higher in the LA and SLA groups compared with C and SC groups, (Table 3). L. sonchoids water extracts increased the water content as well as degree of succulence of the wheat root and shoot either the seeds at pre-soaked in $\mathrm{SA}$ or $\mathrm{H}_{2} \mathrm{O}$. Meanwhile at LA groups the increase was more obivious than that of SLA groups. At LA and SLA groups water content and degree of succulence gradually increase in seedling roots with increasing extract concentration. Water content and degree of succulence gradually decrease in the seedling shoots of SLA groups from SLA to $\mathrm{SLA}_{4}$. The pre-treatment with SA decrease the water content of the seedlings with stress only. Szepesi et al., (2005) reported that SA pre-treatments reduced $\mathrm{K}^{+}$contents of leaves and increased water potential under stress, so water content and degree of succulence decrease by increasing stress.

TABLE 3. Effect of diluted extracts of Launae sonchoids on root and shoot water content (WC) and degree of succulence (D. Su.) of 8 days old wheat plants pre-soaked or none soaked in salicylic acid.

\begin{tabular}{|l|l|l|l|l|}
\hline \multirow{2}{*}{ Treatments } & \multicolumn{2}{|c|}{ Root } & \multicolumn{2}{c|}{ Shoot } \\
\cline { 2 - 5 } & WC \% & D. Su. & W.C \% & D. Su. \\
\hline C & 46.44 & 1.88 & 70.93 & 3.44 \\
LA1 & 47.83 & $1.92^{*}$ & 72.83 & 3.68 \\
LA2 & 51.90 & 2.08 & 85.90 & 7.09 \\
LA3 & $56.73^{*}$ & 2.31 & $88.89^{*}$ & $9.00^{*}$ \\
LA4 & $58.24^{*}$ & 2.39 & $88.24^{*}$ & $8.89^{*}$ \\
LSD, LA (5\%) & 0.87 & 0.08 & 1.17 & 0.07 \\
SC & 41.83 & 1.72 & 71.83 & 3.52 \\
SLA1 & 44.44 & 1.80 & 74.44 & 3.91 \\
SLA2 & 47.12 & 1.89 & 74.12 & 3.86 \\
SLA3 & 49.97 & 2.00 & 72.97 & 3.7 \\
SLA4 & 51.37 & 2.04 & 70.37 & 3.38 \\
LSD, SLA (5\%) & 0.62 & 0.07 & 1.02 & 0.08 \\
\hline
\end{tabular}

Means within a column followed by different number of stars are significantly different according to Fisher's, ${ }^{*}=$ Significant at $\mathrm{P}<0.5^{* *}=$ Significant at $\mathrm{P}<0.1{ }^{* * *}=$ Significant at $\mathrm{P}<0.05$

Priming treatments significantly affected fresh and dry weight of wheat seedlings (Table 4). Fresh weights of seedlings was drastically decreased due to high concentration of $L$. sonchoids water extract, meanwhile low concentration $\left(\mathrm{LA}_{1}\right.$ and $\left.\mathrm{SLA}_{1}\right)$ improved fresh and dry weight of seedlings as compared with control with or without pre-soaked in SA. The reduction of fresh and dry weight reached to $65 \%$ at seedlings treated with $\mathrm{LA}_{4}$. Meanwhile the reduction reached to about $44 \%$ at $\mathrm{SLA}_{4}$ at the same concentration of $L$. sonchoids extract. Seedlings pre-treatment with SA prevented the decreement in biomass caused by stress. Moreover seedlings pre-treatment with SA (SC) had higher biomass than control seedlings.

Pre-treatment with SA regulate the nascent polypeptide-associated complex (NAC) during seeds germination. NAC is a heterodimeric complex that can reversibly bind to eukaryotic ribosome's (Rospert et al., 2002). It is presumed to prevent ribosome-associated nascent polypeptide from inappropriate interaction 
with proteins in the cytosol (Wiedmann et al., 1994). Yan et al. (2005) demonstrated that the NAC was down-regulated in rice (Oryza sativa) roots submitted to stress. Also, a proteomic study of sugar beet (Beta vulgaris) leaves identified the $\alpha$-chain NAC as being down-regulated in response to stress (Hajheidari et al., 2005). Jumali et al. (2011) showed that most genes responding to acute SA treatment are related to stress and signaling pathways which eventually led to cell death. This include genes encoding chaperone, heatshock proteins (HSPs), antioxidants and genes involved in secondary metabolite biosynthesis, such as sinapyl alcohol dehydrogenase (SAD), cinnamyl alcohol dehydrogenase (CAD) and Cytochrome P450 (CYP 450).

TABLE 4. Effect of diluted extracts of $L$. sonchoids on fresh weight (F.W) and dry weight (D.W) of 8 days old plants pre-soaked or none soaked in salicylic acid. Values are the means \pm SEM of three replicated measurements.

\begin{tabular}{|l|l|l|l|l|}
\hline \multicolumn{1}{|c|}{ Treatments } & \multicolumn{2}{|c|}{ Root (g/plant) } & \multicolumn{2}{c|}{ Shoot (g/plant) } \\
\cline { 2 - 5 } & F.W & D. W & F.W & D. W \\
\hline C & 0.048 & 0.020 & 0.079 & 0.022 \\
LA1 & 0.051 & 0.026 & 0.086 & 0.028 \\
LA2 & 0.044 & $0.011^{*}$ & 0.074 & 0.021 \\
LA3 & $0.033^{* *}$ & $0.01^{*}$ & 0.063 & 0.017 \\
LA4 & $0.022^{* * *}$ & $0.008^{* *}$ & $0.034^{* *}$ & $*$ \\
LSD, LA (5\%) & 0.005 & 0.004 & 0.008 & 0.011 \\
SC & 0.058 & 0.023 & 0.094 & $*$ \\
SLA1 & 0.061 & 0.025 & 0.10 & 0.002 \\
SLA2 & 0.048 & 0.018 & 0.085 & 0.037 \\
SLA3 & 0.043 & 0.015 & 0.074 & 0.042 \\
SLA4 & $0.032^{* *}$ & $0.011^{*}$ & 0.054 & 0.022 \\
LSD, SLA (5\%) & 0.006 & 0.005 & 0.01 & 0.020 \\
& & & & $*$ \\
& & & & 0.016 \\
& & & & 0.002 \\
\hline
\end{tabular}

Means within a column followed by different number of stars are significantly different according to Fisher's ${ }^{*}=$ Significant at $\mathrm{P}<0.5^{* *}=$ Significant at $\mathrm{P}<0.1{ }^{* * *}=$ Significant at $\mathrm{P}<0.05$

Effect of Launae sonchoids extracts on chlorophyll contant of wheat seedlings (pre-soaked or none soaked in salicylic acid)

Total chlorophyll was determined in wheat green tissues under the effect of irrigation with $L$. sonchoids extract. In $\mathrm{LA}_{1}$ and $\mathrm{SLA}_{1}$ seedlings, total chlorophyll was higher than those of $\mathrm{C}$ and $\mathrm{SC}$ seedlings, (Table 5). Meanwhile increasing the extract concentration from $\mathrm{LA}_{2}$ and $\mathrm{SLA}_{2}$ to $\mathrm{LA}_{4}$ and $\mathrm{SLA}_{4}$ were associated with gradually decrease of chlorophyll contents. Yang et al., (2002) showed that allelochemical may reduce chlorophyll accumulation in three ways: The inhibition of chlorophyll biosynthesis, the stimulation of chlorophyll degradation, or both. The present study strongly indicates that chlorophyll biosynthesis of wheat seedlings was effacted by the allelopathic effect of Launae sonchoids water extracts. 
Seedlings pre-treatment with SA prevented the decrease in chlorophyll content caused by $L$. sonchoids extract stress. Since SA improved the photosynthetic performance of plants under stress conditions (Ananieva et al., 2002), and chlorophyll a fluorescence could give insight into the ability of a plant to tolerate environmental stresses. This can be partially overcome if plants are pre-treated with SA. Since under non-photorespiratory conditions the effective quantum yield of PSII provides useful information concerning photosynthetic performance of $\mathrm{C} 3$ plants, these results suggests that SA pretreatment may improve the gross rate of carbon assimilation during allopathic stress. In the presence of SA, leaves accumulated different compatible osmolytes, such as sugars, sugar alcohol and proline. SA pre-treatment decreased the CAT activity both in the roots and leaves, but the activity of other enzymes associated with the antioxidative defense, superoxide dismutases (SOD), peroxidase (POD), ascorbate peroxidase (APX) and glutathione reductase (GR) exhibited different changes. As a general rule, the activity of these enzymes (CAT, SOD, POD and APX) decreased compared to the control in the leaves of tomato plants (Szepesi et al., 2005).

TABLE 5. Effect of diluted extracts of Launae sonchoids on chlorophyll $(\mathbf{a}+\mathbf{b})$ content (ug/g F.W) of wheat seedlings pre-soaked or none soaked in salicylic acid. Values are the means \pm SEM of three replicated measurements.

\begin{tabular}{|l|c|c|c|c|}
\hline \multirow{2}{*}{ Treatments } & \multicolumn{4}{|c|}{ Time (days) } \\
\cline { 2 - 5 } & $\mathbf{2}$ & $\mathbf{4}$ & $\mathbf{6}$ & $\mathbf{8}$ \\
\hline LA1 & $148 \pm 6$ & $212 \pm 11$ & $326 \pm 16$ & $564 \pm 21$ \\
LA2 & $167 \pm 6$ & $238 \pm 15$ & $390 \pm 18^{* *}$ & $586 \pm 26$ \\
LA3 & $112 \pm 4^{*}$ & $176 \pm 7^{* *}$ & $256 \pm 14^{* * *}$ & $420 \pm 16^{* *}$ \\
LA4 & $84 \pm 3^{* *}$ & $151 \pm 4^{* * *}$ & $174 \pm 5^{* * * *}$ & $280 \pm 6^{* * * *}$ \\
LSD, LA (5\%) & $42 \pm 2^{* * *}$ & $94 \pm 4^{* * *}$ & $116 \pm 6^{* * * *}$ & $165 \pm 8^{* * *}$ \\
SC & 1.2 & 0.65 & 0.55 & 0.43 \\
SLA1 & $164 \pm 9$ & $256 \pm 16$ & $422 \pm 6$ & $629 \pm 18$ \\
SLA2 & $193 \pm 11$ & $290 \pm 16$ & $460 \pm 16$ & $656 \pm 14$ \\
SLA3 & $184 \pm 4$ & $210 \pm 11$ & $324 \pm 14$ & $512 \pm 14$ \\
SLA4 & $134 \pm 4^{*}$ & $191 \pm 9^{* *}$ & $300 \pm 11^{* *}$ & $470 \pm 13^{* * *}$ \\
LSD, SLA (5\%) & $103 \pm 3^{* *}$ & $114 \pm 4^{* * *}$ & $216 \pm 10^{* *}$ & $315 \pm 9^{* * *}$ \\
\hline
\end{tabular}

Means within a column followed by different number of stars are significantly different according to Fisher's, ${ }^{*}=$ Significant at $\mathrm{P}<0.5^{* *}=$ Significant at $\mathrm{P}<0.1^{* * *}=$ Significant at $\mathrm{P}<0.05$

Pre-treatment of wheat seeds with salicylic acid led to enhanced seedling tolerance to condition of stress during germination, as evidenced by the greater growth of SLA versus LA seedlings evaluated through such parameters as length and biomass of, root and shoot as well as chlorophyll content (Tables 1-4). Szepesi et al. (2005) showed that SA substantially improved tomato germination vigor under stress conditions. Sakhabutdinova et al. (2003), showed that pre-sowing treatment with SA completely prevented stress induced declines in the concentration of IAA and cytokines in seedlings and reduced accumulation of $\mathrm{ABA}$, which might be a prerequisite for acceleration of growth. 
Moharekar et al. (2006) reported that salicylic acid, application increased chlorophyll content in both wheat and moong seedlings. Meanwhile Taşgin et al. (2005) concluded that exogenous SA can be involved in cold tolerance by regulating apoplastic proteins and antioxidant enzyme activities.

Effect of Launae sonchoids extracts on levels of compatible osmolytes of wheat seedlings (pre-soaked or none soaked in salicylic acid)

Total betaine content reached the maximum level (26 ug /g DW and $18.7 \mathrm{ug} / \mathrm{g}$ DW) for SC and C, respectively on the eight day of germination without $L$ sonchoids extract (Table 6). All extracts showed an inhibitory effect on total betaine content of wheat. However, the SLA samples that were pre-soaked in SA showed different degrees of an inhibitory effect.

TABLE 6. Effect of diluted extracts of Launae sonchoids on the total betaine levels (ug/g DW) of wheat seedlings pre-soaked or none soaked in salicylic acid. Values are the means \pm SEM of three replicated measurements.

\begin{tabular}{|l|c|c|c|c|}
\hline \multirow{2}{*}{ Treatments } & \multicolumn{4}{|c|}{ Time (days) } \\
\cline { 2 - 5 } & $\mathbf{2}$ & $\mathbf{4}$ & $\mathbf{6}$ & $\mathbf{8}$ \\
\hline C & $4.2 \pm .0 .3$ & $8.5 \pm 0.4$ & $13.2 \pm 0.5$ & $18.7 \pm 0.8$ \\
LA1 & $3.8 \pm 0.3$ & $7.5 \pm 0.3$ & $12.5 \pm 0.5$ & $17.8 \pm 0.7$ \\
LA2 & $3.3 \pm 0.2^{*}$ & $7.1 \pm 0.3^{*}$ & $10.8 \pm 0.5^{*}$ & $15.6 \pm 0.7^{*}$ \\
LA3 & $2.5 \pm 0.2^{* *}$ & $6.5 \pm 0.2^{*}$ & $9.5 \pm 0.4^{*}$ & $12.4 \pm 0.6^{* *}$ \\
LA4 & $2 \pm 0.2^{* * *}$ & $5.1 \pm 0.2^{* *}$ & $8.4 \pm 0.4^{*}$ & $10.7 \pm 0.6^{* * *}$ \\
LSD, LA (5\%) & 0.05 & 0.06 & $0.08^{* * *}$ & 0.09 \\
SC & $4.6 \pm 0.1$ & $11.2 \pm 0.4^{*}$ & $19.5 \pm 1^{* * *}$ & $26 \pm 2^{* * * *}$ \\
SLA1 & $4.1 \pm 0.2$ & $10.7 \pm 0.4^{*}$ & $18 \pm 1^{* * *}$ & $25.7 \pm 2^{* * *}$ \\
SLA2 & $3.8 \pm 0.2$ & $10.1 \pm 0.5^{*}$ & $17.8 \pm 0.7^{* *}$ & $24.8 \pm 2^{* *}$ \\
SLA3 & $3.5 \pm 0.2$ & $9.8 \pm 0.3$ & $16.8 \pm 0.7^{* *}$ & $21.4 \pm 2^{*}$ \\
SLA4 & $3.2 \pm 0.2^{*}$ & $8.7 \pm 0.3$ & $14.4 \pm 0.6^{*}$ & $17.9 \pm 0.9$ \\
LSD, SLA (5\%) & 0.05 & 0.07 & 0.09 & 0.10 \\
\hline
\end{tabular}

Means within a column followed by different number of stars are significantly different according to Fisher's $*=$ Significant at $\mathrm{P}<0.5 * *=$ Significant at $\mathrm{P}<0.1 * * *=$ Significant at $\mathrm{P}<0.05$

Pre-treatment with salicylic acid led to a significant increase in betaine levels in SC and SLA groups versus C and LA seedlings. Such an increase may be attributed to the fact that the addition of this precursor (salicylic acid) promotes betaine formation by stimulating its biosynthesis (Hitz et al., 1982). The protective role of betaine against stresses in higher plants, in bacteria and in animals is widely recognized (Rhodes \& Hanson, 1993).The significant increase of this osmolytes in plant tissue of pre-treated with SA would help to explain the increase in tolerance to allelopathy. The accumulation recorded in seedlings starting from the fourth day could be responsible for the enhanced growth observed in SLA versus LA seedlings, as well as for preventing the decrease in chlorophyll content.

Glutathione content was decreased by L. sonchoids extract treatments (Table 7). However, at SLA the glutathione values increased after 8 days compared with C

Egypt. J. Agron. 34, No. 1 (2012) 
and SC groups. Adaptation to L. sonchoids extract involves increases in the antioxidant capacity of the cell to detoxify reactive oxygen species (Bellaire et al., 2000). In concordance to Hernadez et al. (2000), the glutathione (GSH) content could indicate that this antioxidant soluble compound was involved in the stress tolerance. The increase in glutathione content due to SA treatment enhanced tolerance may be totally or partly due to increased GSH synthesis and/or decrease rates of degradation (Noctor \& Foyer, 1998). Exogenous SA treatment leads to increased antioxidant capacity in barley (Hordeum vulgare) leaves (Ananieva et al., 2002) and stimulates peroxidase/catalase activities in plant cells (Dixon et al., 1995) because of an enhanced accumulation of hydrogen peroxide under such conditions (Rao et al., 1997). It is known that stress induces the generation of reactive oxygen species in plants (Polle, 1997 and Borsani et al., 2001). Thereby, it is possible that the presently observed induction of such enzymes by SA can provide an explanation for the improvement of $T$. aestivum seed germination under stress.

TABLE 7. Effect of diluted extracts of Launae sonchoids on the glutathione content (ug/g DW) of wheat seedlings pre-soaked or none soaked in salicylic acid. Values are the means \pm SEM of three replicated measurements.

\begin{tabular}{|l|c|c|c|c|}
\hline \multirow{2}{*}{ Treatments } & \multicolumn{4}{|c|}{} \\
\cline { 2 - 5 } & $\mathbf{2}$ & $\mathbf{4}$ & $\mathbf{6}$ & $\mathbf{8}$ \\
\hline & & & & \\
C & $15.2 \pm 0.8$ & $19.4 \pm 0.9$ & $15.2 \pm 0.5$ & $13.7 \pm 0.5$ \\
LA1 & $13.8 \pm 0.7$ & $17.5 \pm 0.7$ & $13.5 \pm 0.5$ & $10.8 \pm 0.4$ \\
LA2 & $11.3 \pm 0.7^{*}$ & $17.1 \pm 0.7$ & $10.7 \pm 0.5^{*}$ & $8.6 \pm 0.3^{* *}$ \\
LA3 & $9.5 \pm 0.6^{* *}$ & $15.5 \pm 0.6^{*}$ & $7.5 \pm 0.4^{* *}$ & $6.4 \pm 0.2^{* * *}$ \\
LA4 & $7.2 \pm 0.5^{* * *}$ & $11.1 \pm 0.6^{* *}$ & $7.1 \pm 0.4^{* *}$ & $5.7 \pm 0.3^{* * *}$ \\
LSD, LA (5\%) & 0.08 & 0.1 & 0.07 & 0.06 \\
SC & $17.4 \pm 1$ & $21.8 \pm 2^{*}$ & $18.5 \pm 1^{*}$ & $17 \pm 2^{* *}$ \\
SLA1 & $16.1 \pm 0.8$ & $20.1 \pm 1.4^{*}$ & $16 \pm 1^{*}$ & $18.7 \pm 2^{* *}$ \\
SLA2 & $15.8 \pm 0.7$ & $19.4 \pm 1^{*}$ & $14.8 \pm 0.7$ & $20.8 \pm 2^{* * *}$ \\
SLA3 & $14.5 \pm 0.6$ & $19 \pm 1$ & $13.6 \pm 0.7$ & $22.4 \pm 2^{* * *}$ \\
SLA4 & $11 \pm 0.5^{*}$ & $17.8 \pm 0.8$ & $11.4 \pm 0.6^{*}$ & $17.3 \pm 0.8^{* *}$ \\
LSD, SLA (5\%) & 0.13 & 0.15 & 0.1 & 0.1 \\
& & & & \\
\hline
\end{tabular}

Means within a column followed by different number of stars are significantly different according to Fisher's, ${ }^{*}=$ Significant at $\mathrm{P}<0.5^{* *}=$ Significant at $\mathrm{P}<0.1^{* * * *}=$ Significant at $\mathrm{P}<0.05$

Effect of Launae sonchoids extracts on nitrogenous fractions of wheat seedlings (pre-soaked or none soaked in salicylic acid)

It is clear from Table 8 that the values recorded for total nitrogen, soluble nitrogen; insoluble nitrogen and crude protein were decreased by the treatment with $L$. sonchoids extract. The depression induced by the highest level of $L$. sonchoids extract reached to $50 \%$ of that control, while the pre-soaked in SA reduced depression to less than $40 \%$. 
Egypt. J. Agron. 34, No. 1 (2012) 
The pre-soaked with salicylic acid improved all nitrogenous fractions (Table 8). Gunes et al. (2007) reported that, salicylic acid acts as endogenous signal molecule responsible for inducing abiotic stress tolerance in plants. They emphasized that exogenous application of SA increased plant growth significantly both in stress and non stress conditions. Plants produce proteins in response to abiotic and biotic stress and many of these proteins are induced by phytohormones such as ABA and salicylic acid (Hoyos \& Zhang, 2000). Moreover Gunes et al. (2007) demonstrated that exogenously applied SA increased plant growth significantly by improving the uptake of $\mathrm{N}, \mathrm{Mg}, \mathrm{Fe}, \mathrm{Mn}$, and $\mathrm{Cu}$ or induced protein biosynthesis. Other processes affected by SA concerned the quality of protein translation, the priming of seed metabolism, the synthesis of antioxidant enzymes, and the mobilization of seed storage proteins. All the observed effects are likely to improve seed vigor (Rajjou et al., 2006).

The mode of action of an allelochemicals can broadly be divided into a direct and an indirect action (Rizvi et al., 1992). Effects through the alternation of soil properties, nutritional status and an altered population or activity of micro-organisms and nematodes represent the indirect action. The direct action involves the biochemical/physiological effects of allelochemicals on various important processes of plant growth and metabolism. Processes influenced by allelochemicals involve mineral uptake. Allelochemicals can alter the rate the ions absorbed by plants. A reduction in both macro- and micronutrients are encountered in the presence of phenolic acids (Bhadoria, 2011). Phytohormones and balanced plant growth hormones [indoleacetic acid (IAA) and gibberellins (GA)] regulate cell enlargement in plants. IAA is present in both active and inactive forms, and is inactivated by IAA- oxidase. IAA- oxidase is inhibited by various allelochemicals (Bhadoria, 2011).

Once the mechanism of SA action is better understood, new opportunities for agricultural biotechnology may become evident. Alongside unraveling the SA mode of action, other aspects such as uptake, transport and stability of SA as well as the development of SA analogues with high activity, should continue to be explored. It is only with this combined knowledge that unique mechanisms of stress resistance can lead to implementations, with predictable effects of SA application in the field, allowing for the full potential of SA to be harnessed in the future. Plants produce proteins in response to abiotic and biotic stress and many of these proteins are induced by phytohormones such as ABA (Jin \& Chen, 2000) and salicylic acid (Hoyos \& Zhang, 2000). Salicylic acid is an endogenous growth regulator of phenolic nature, which influence a range of diverse processes in plants, including seed germination (Cutt \& Klessig, 1992), stomatal closure (Larque-Saaveda, 1979); ion uptake and transport ( Harper \& Balke, 1981), membrane permeability (Barkosky \& Einhellig, 1993), photosynthetic and growth rate (Khan et al., 2003).

SA treatment caused accumulation of both $\mathrm{ABA}$ and IAA in wheat seedlings under salinity (Javid et al., 2011), however, the SA treatment did not influence

Egypt. J. Agron. 34, No. 1 (2012) 
on cytokinin content. Thus, protective SA action includes the development of antistress programs and acceleration of normalization of growth processes after removal stress factors (Sakhabutdinova et al., 2003). The results obtained strongly argue that SA could be a very promising compound for alleviation of the allelopathic stress sensitivity of wheat due to mitigate the damaging effects of various stress factors in the plant.

\section{Conclusions}

Our results indicate that salicylic acid alleviat the allopathic effect of Launae sonchoids on wheat plant growth. The aqueous extract of L. sonchoids decreases the growth parameter of wheat. The pre-soaked wheat seeds in $0.05 \mathrm{mM}$ salicylic (SA) increase the tolerance to allelopathy of $L$. sonchoids. Betaine levels, chlorophyll, glutathione and nitrogenous fractions contents increased in the pretreated seedlings with salicylic acid as scavators. A relationship between nitrogenous fractions, antioxidant glutathione and Launae sonchoids extract tolerance observed in wheat seedlings with or without salicylic acid. It was concluded that SA could be used as a potential growth regulator to improve allelopathic tolerance in wheat plant.

\section{References}

Afzal, I., Basara, S.M.A., Faooq, M. and Nawaz, A. (2006) Alleviation of salinity stress in spring wheat by hormonal priming with ABA, salicylic acid and ascorbic acid. Int. J. Agric. Biol. 8, 23-28.

Ananieva, E.A., Alexieva, V.S. and Popova, L.P. (2002) Treatment with salicylic acid decreases the effects of paraquate on photosynthesis. J. Plant Physiol. 159, 685-693.

Association of Official Analytical Chemist (AOAC) (1980) "Official Methods of Analysis" (13 ${ }^{\text {th }}$ ed). Washington D.C.

Azooz, M.M. (2009) Salt stress initigation by seed priming with salicylic acid in two faba bean genotypes differing in salt tolerant. Int. J. Agric. Biol. 11, 343-350.

Barkosky, R.R. and Einhellig, F.A. (1993) Effects of salicylic acid on plant water relationship. J. Chemical Ecolology, 19, 237-247.

Bellaire, B.A., Carmody, J., Braud, J., Gosset, D.R., Banks, S.W. and Cran Lucas, M. (2000) Involvement of abscisic acid-dependent and independent pathways in the up regulation of antioxidant enzyme activity during $\mathrm{NaCl}$ stress in cotton callus tissue. Free Rad. Res. 33, 531-545.

Ben Hammouda, M., Habib, G.; Kremer, R.J. and Oussama, O. (2001) Allelopathic effects of barley extracts on germination and seedlings growth of bread and durum wheats. Agronomie, 21, 65-71. 
Bertholdesson, N.O. (2005) Early vigour and allelopathy - two useful traits for enhanced barley and wheat competitiveness against weeds. Weed Res. 45 (2), 94102.

Bhadoria, P.B.S. (2011) Allelopathy: A natural way towards, weed management. Am. $J$. Exp. Agric. 1(1), 7-20.

Borsani, O., Valpuesta, V. and Botella, M.A. (2001) Evidence for a role of salicylic acid in the oxidative damage generated by $\mathrm{NaCl}$ and osmotic stress in Arabidopsis seedlings. Plant Physiol. 126,1024-1030.

Bosch, S.M., Penuelas, J. and Liusia, J. (2007) A deficiency in salicylic acid alters isoprenoid accumulation in water stressed NahG transgenic Arabidopsis plants. Plant Sci. 172 (4), 756-762.

Cutt, J.R. and Klessig, D. F. (1992) Salicylic acid in plants. A changing perspective. Pharmacetical Technology, 16, 25-34.

Dat, J.F., Lopez-Delgado, H., Foyer, C.H. and Scott, I.M. (1998) Parallel changes in $\mathrm{H}_{2} \mathrm{O}_{2}$ and catalase during thermo-tolerance induced by salicylic acid or heat acclimation in mustard seedlings. Plant Physiol. 116, 1351-1357.

Dixon, R.A., Paiva, N.L. and Bhattacharyya, M.K. (1995) Engineering disease resistance in plants: an overview. In: "Molecular Methods in Plant Pathology" Singh, R.P. Singh. U.S. (Ed.) CRC Press, Boca Raton, FL, pp 249-270.

Duke, S.O., Dayan, F.E., Romagni, J.G. and Rimando, A.M. (2000) Natural products as sources of herbicides: current status and future trends. Weed Res. 40, 99-111.

Einhellig, F.A. (2002) The physiology of allelochemical action: clues and views. In: "Allelopathy, from Molecules to Ecosystems", M.J. Reigosa and N. Pedrol (Ed.). Science Publishers, Enfield, New Hampshire.

Fay, P.K. and Duke, W.B. (1977) An assessment of allelopathic potential in Avena germplasm. Weed Sci. 25, 224-228.

Gunes, Y., Inal, A., Alpaslan, M., Eraslan, F., Bagci, E. G. and Cicek, G. N. (2007) Salicylic acid induced changes on some physiological parameters symptomatic for oxidative stress and mineral nutration in maize (Zea mays L.) grown under salinity. J. Plant Physiol. 55, 207-213.

Hajheidari, M., Abdollahian-Noghabi, M., Askari, H., Heidari, M., Sadeghian, S.Y., Ober, E.S. and Salekdeh, G.H. (2005) Proteome analysis of sugar beet leaves under drought stress. Proteomics, 5, 950-960.

Halsey, R.W. (2004) In search of allelopathy: An eco-historical view of the investigation of chemical inhibition in California coastal sage scrub and chamise chaparral. J. the Torrey Botanical Soc. 131, 343-367.

Harper, J.P. and Balke, N.E. (1981) Characterization of the inhibition of $\mathrm{K}^{+}$absorption in oat roots by salicylic acid. Plant Physiol. 68, 1349-1353. 
Hayat, Q., Hayat, S., Irfan, M. and Ahmad, A. (2010) Effect of exogenous salicylic acid under changing environment: A review. Environ Exp. Bot. 68, 14-25.

Hernadez, J.A., Jimenez, A., Mullineaux, P. and Sevilla, F. (2000) Tolerance of pea (Pisum sativum L.) to long-term salt stress in associated with induction of antioxidant defenses. Plant Cell. Environ. 23, 853-862.

Hitz, W.D., Ladyman, J.A.R. and Hanson, A.D. (1982) Betaine synthesis and accumulation in barley during field water stress. Crop Sci. 22, 47-54.

Horváth, E., Janda, T., Szalai, G. and Páldi, E. (2002) In vitro salicylic acid inhibition of catalase activity in maize: differences between the iso-enzymes and a possible role in the induction of chilling tolerance. Plant Sci. 163, 1129-1135.

Horváth, E., Szalai, G. and Janda, T. (2007) Induction of Abiotic stress tolerance by salicylic acid signaling. J. Plant Growth Regul. 26, 290-300.

Hoyos, M.E. and Zhang, S.Q. (2000) Calcium-independent activation of salicylic acidindcued protein kinase and a 40-kilodalton protein kinase by hyperosmotic stress. Plant Physiol. 122, 1355-1363.

Hussein, M.M., Balbaa, L.K. and Gaballah, M.S. (2007) Salicylic acid and salinity effects on growth of maize plants. Res. J. Agric. \& Biol. Sci. 3(4), 321-328.

Javid, M.G., Sorooshzadeh, A., Foad, M., Mohammad, S.A., Sanavy, M. and Allahdadi, I. (2011) The role of phytohormones in alleviating salt stress in crop plants. Aust. J. Crop. 5 (6), 726-734.

Jin, S. and Chen, C.C.S. (2000) Plant, A. L. Regulation by ABA of osmotic stress induced changes in protein synthesis in tomato roots. Plant Cell and Environ. 23, 5160 .

Jumali, S.S., Said, I.M., Ismail, I. and Zainal, Z. (2011) Genes induced by high concentration of salicylic acid in Mitragyna speciosa. Aust. J. Crop Sci. 5, 296- 303.

Khan, W., Prithiviraj, B. and Smith, H. (2003) Photosynthetic responses of corn and soybean to foliar application of salicylates. J. Plant Physiol.18.

Khanh, T.D., Chung, M.I., Tawata, S. and Xuan, T.D. (2007) Allelopathy for weed management in sustainable agriculture, CAB Reviews: Perspectives in Agriculture, Veterinary Science, Nutrition and Natural Resources, 34, 17

Kil, B.S. and Yun, K.W. (1992) Allelopathic effects of water extract of Artemisia princeps var. orientalis on selected plant species. J. Chem. Ecol. 18, 39-51.

Larque-Saaveda, A. (1979) Stomatal closure in response to salicylic acid treatment. Z. Pflanzenphysiology, 93, 371-375.

Lerma, C., Rich, P.J., Yang, W.J., Hanson, A.D. and Rhodes, D. (1991) Betaine deficiency in maize. Plant Physiol. 95, 1113-1119.

Egypt. J. Agron. 34, No. 1 (2012) 
Moharekar, S.T., Lokhande, S.D., Hara, R., Tanaka, A., Tanaka, S. and Chavan, P.D. (2006) Effect of salicylic acid on chlorophyll and carotenoid contents of wheat and moong seedlings. Photosynthetica, 41(2), 157-164.

Monari, A.M., Marco, C., Urbano, S.M., Margiotta, B. and Lafiandra, D. (2005) Molecular characterization of new waxy mutants identified in bread and durum wheat. Theoretical and Applied Genetics, 110, (8), 1481.

Noctor, G. and Foyer, C.H. (1998) Ascorbate and glutathione of keeping active oxygen under control. Ann. Rev. Plant Physiol.\& Plant Mol. Biol. 49, 249-279.

Noreen, S. and Ashraf, M. (2008) Alleviation of adverse effects of salt stress on sunflower (Helianthus annuus L.) by exogenous application of salicylic acid: Growth and photosynthesis. Pak. J. Bot. 40(4), 1657-1663.

Oussama, O. (2003) Allelopathy in two durum wheat (Triticum durum L.) varieties. Agri. Ecos. \& Eniviron. 96, 161-163.

Pirie, F.G. (1955) Proteins. - In: "Modern Methods of Plant Analysis". Peach, K., Tracey, V.M. (Ed.): Vol. IV. 23. Springer-Verlag, Berlin.

Polle, A. (1997) Defence against photo-oxidative damage in plants. In: "Oxidative Stress and Molecular Biology of Antioxidant Defences". J.G. Scandalios, Ed, Cold Spring Harbor Laboratory Press, Cold Spring Harbor, NY, pp. 623-666.

Rajjou, L., Gallardo, K., Job, C. and Job, D. (2006) Proteome analysis for the study of developmental processes in plants. In: "Plant Proteomics". C. Finnie (Ed.) Blackwell Publishing, Oxford, pp. 151-184.

Rao, M.V. and Davis, R.D. (1999) Ozone-induced cell death occurs via two distinct mechanisms in Arabidopsis: the role of salicylic acid. Plant J. 17, 603-614.

Rao, M.V., Paliyath, G., Ormrod, D.P., Murr, D.P. and Watkins, C.B. (1997) Influence of salicylic acid on $\mathrm{H}_{2} \mathrm{O}_{2}$ production, oxidative stress, and $\mathrm{H}_{2} \mathrm{O}_{2-}$ metabolizing enzymes: salicylic acid-mediated oxidative damage requires $\mathrm{H}_{2} \mathrm{O}_{2}$. Plant Physiol. 115, 137-149.

Rasmussen, J., Kurtzmann, J. I. and Jensen, A. (2004) Tolerance of competitive spring barley cultivars to weed harrowing. Weed Res. 44 (6), 446-452.

Regina, G. and Belz, M. (2007) Allelopathy in crop/weed interactions?. Pest Management Sc. 63 (4), 308.

Rhodes, D. and Hanson, A. D. (1993) Quaternary ammonium and tertiary sulfonium compounds in higher plants. Ann .Rev. Plant Physiol. 44, 357-384.

Rhodes, D., Rich, P.R., Myers, A.C., Reuter, C. R. and Jamieson, G.C. (1987) Determination of betaine by fast atom bombardment mass spectrometry: Identification of glycine betaine deficient genotypes of Zea mays L. Plant Physiol., 84, 781-788.

Rice, E.L., (1984): “Allelopathy”. $2^{\text {nd }}$ ed. Academic Press, London. 
Rizvi, S.J.H., Haque, H., Singh, V.K. and Rizvi, V. (1992) A discipline called allelopathy. In: "Allelopathy: Basic and Applied aspects". S.J.H. Rizvi, \& V. Rizvi (Ed.). Chapmann \& Hall Publishers. pp.1-8.

Rospert, S., Dubaquie, Y. and Gautschi, M. (2002) Nascent-polypeptide-associated complex. Cell Mol. Life Sci. 59, 1632-1639.

Sakhabutdinova, A.R., Fatkhutdinova, D.R., Bezrukova, M.V. and Shakirova, F. M. (2003) Salicylic acid prevents damaging action of stress factors on wheat plants. Bulg. J. Physiol. 314-319.

Schupp, R. and Rennenberg, H. (1988) Diurnal changes in the glutathione content of spruce needles (Picea abies L.). Plant Sci. 57, 113-117.

Szalai, G., Tari, I., Janda, T., Pestenácz, A. and Páldi, E. (2000) Effects of cold acclimation and salicylic acid on changes in ACC and MACC contents in maize during chilling. Biol. Plant, 43, 637-640.

Szepesi, Á., Csiszár, J., Bajkán, S., Gémes, K. and Horváth, F. (2005) Role of salicylic acid pre-treatment on the acclimation of tomato plants to salt- and osmotic stress. Acta Biologica Szegediensis, 49 (1), 123-125.

Tari, I., Csiszár, J., Szalai, G., Horváth, F., Pécsváradi, A., Kiss, G., Szepesi, Á., Szabó, M. and Erdei, L. (2002) Acclimation of tomato plants to salinity stress after a salicylic acid pre-treatment. Acta Biol. Szeged, 46 (3-4), 55-56.

Taşgın , E., Atıcı, O., Nalbantoğlu, B. and Petrova, L. (2005) Effects of salicylic acid and cold treatments on protein levels and on the activities of antioxidant enzymes in the apoplast of winter wheat leaves. Bulgarian Academy of Sciences, Sofia, Bulgaria,13 (2), 34-41.

Wahid, A., Perveen, M., Gelani, S. and Basra, S.M.A. (2007) Pretreatment of seed with $\mathrm{H}_{2} \mathrm{O}_{2}$ improves salt tolerance of wheat seedlings by alleviation of oxidative damage and expression of stress proteins. J. Plant Physiol. 164, 283-294.

Wall, J.S., Christianson, D.D., Dilmer, R.J. and Senti, F.R. (1960) Spectrophotometric determination of betaines and other quaternary nitrogen compounds as their periodides. Anal. Chem. 32, 870-874.

Weatherly, P.E. and Barrs, C. (1962) A reexamination of relative turgidity technique for estimating water deficits in leaves. Aust. J.Biol. Sci. 15, 413- 428.

Wiedmann, B., Sakai, H., Davis, T.A. and Wiedmann, M. (1994) A protein complex required for signal-sequence-specific sorting and translocation. Nature, 370, 434 440.

Witham, F.H., Blaydes, D.R. and Devlin, R.M. (1971) "Experiments in Plant Physiology". Van Nostrand Reinhold, New York. pp.1-11. 
Yan, S., Tang, Z.S.W. and Sun, W. (2005) Proteomic analysis of salt stress-responsive proteins in rice root. Proteomics, 5, 235-244.

Yang, C.M., Lee, C.N. and Chou, C.H. (2002) Effects of three allelopathic phenolics on chlorophyll accumulation of rice (Oryza sativa) seedlings: I. Inhibition of supplyorientation. Bot. Bull. Acad. Sin. 43, 299-304.

\section{تخفيف التاثير الألوباثي لحثيثة نبات اللونيا على نمو نباتات القمح باستخدام حمض السالسليك}

$$
\text { قنان السيد ضيف كلية العلوم- جامعة الزقازيق - الثرقية - مصر. }
$$

تمت هذه الدراسة بغرض معالجة التاثير الضار لحشيشة نبات اللونيا على انبات

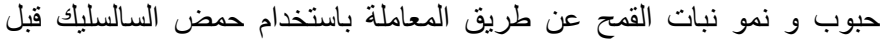

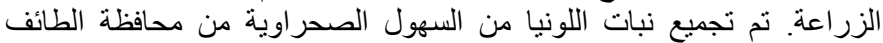

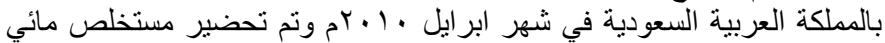

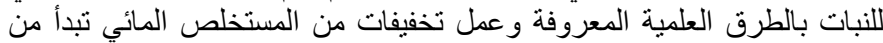

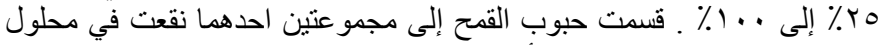

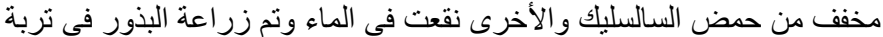

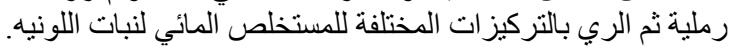

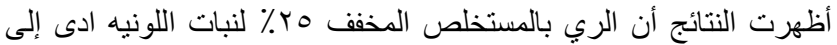

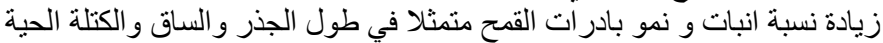

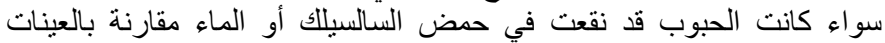

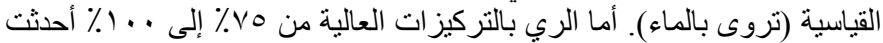

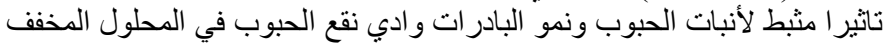

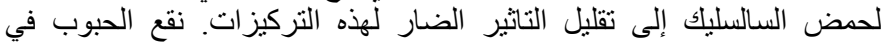

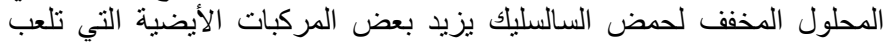

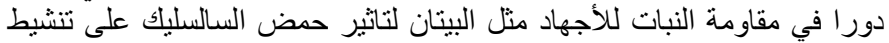

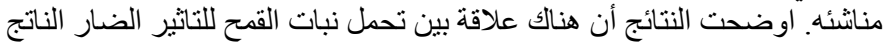

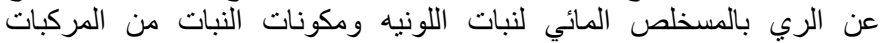

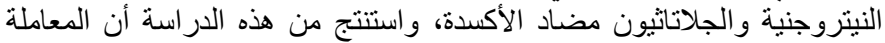

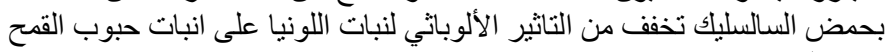

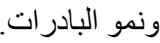

